\title{
Bedrock exfiltration as a triggering mechanism for shallow landslides
}

\author{
Cornelia Brönnimann, ${ }^{1}$ Manfred Stähli, ${ }^{1}$ Philipp Schneider, ${ }^{2}$ Linda Seward, ${ }^{3}$ and Sarah M. Springman ${ }^{3}$ \\ Received 23 May 2012; revised 18 June 2013; accepted 22 June 2013; published 4 September 2013.
}

[1] Shallow landslides pose substantial risks to people and infrastructure in mountain areas. Their occurrence is influenced by groundwater dynamics and bedrock characteristics. The bedrock may drain or contribute to groundwater in the overlying soil mass, depending on the hydraulic conductivity, degree of fracturing, saturation, and hydraulic head. Here, we present a detailed case study for a slope from Central Switzerland, where soil-bedrock interactions were responsible for triggering shallow landslides in the past. The bedrock in the study area represents a succession of heavily fissured conglomerate-sandstone beds and weathered marlstone layers, which are overlain by a clayey soil layer. There is evidence of a temporally confined aquifer in bedrock fractures from a severe storm event in August 2005. We derived a detailed geological model of the slope from electrical resistivity tomography surveys, borehole data, and bedrock outcrops. Then, the groundwater response to 32 rainfall events was monitored in the soil layer and in different bedrock layers from November 2010 to November 2011. We observed a fast and substantial rise of the hydraulic head in the bedrock, which was in contrast to the low permeability of the soil layer. The data suggest that rapid groundwater flow through bedrock fractures caused the immediate increase of the hydraulic head. Our observations document how water pressure builds up in fractured bedrock below a low permeability soil cover during heavy rainfall, which may trigger shallow landslides.

Citation: Brönnimann, C., M. Stähli, P. Schneider, L. Seward, and S. M. Springman (2013), Bedrock exfiltration as a triggering mechanism for shallow landslides, Water Resour. Res., 49, 5155-5167, doi:10.1002/wrcr.20386.

\section{Introduction}

[2] Shallow landslides triggered by heavy rainfall cause substantial damage to exposed infrastructure every year in mountain regions around the world, e.g., in Switzerland [Schmid et al., 2004]. The slip surface of such failures typically develops at less than two meter depth along the soilbedrock interface [Springman et al., 2012]. Prolonged and high-intensity precipitation is known as one of the most important triggers of shallow landslides [Van Asch et al., 1999]. The dominant runoff generation process in steep terrain with conductive soils is usually subsurface stormflow [Weiler et al., 2006]. Increased positive pore water pressure in steep terrain due to infiltration and subsurface stormflow may lead to reduced shear strength of the soil and subsequently may induce slope failure [Lambe and Whitman, 1979; Iverson, 2000]. Many slope stability studies concentrate on hydrological processes occurring in the soil layer

\footnotetext{
${ }^{1}$ Swiss Federal Institute for Forest, Snow and Landscape Research WSL, Birmensdorf, Switzerland.

${ }^{2}$ Hydrology and Climate Division, Department of Geography, University of Zürich, Zürich, Switzerland.

${ }^{3}$ Institute for Geotechnical Engineering, Swiss Federal Institute of Technology, Zürich, Switzerland.

Corresponding author: C. Brönnimann, Swiss Federal Institute for Forest, Snow and Landscape Research WSL, Zürcherstrasse 111, CH-8903 Birmensdorf, Switzerland. (Conae@gmx.net)
}

C2013. American Geophysical Union. All Rights Reserved. 0043-1397/13/10.1002/wrcr.20386 and assume the bedrock interface to be a nearly impermeable boundary below the soil layer [Beven and Germann, 1982; Brammer and McDonnell, 1996; Wang and Sassa, 2003]. Permeable bedrock, including deep percolation or exfiltration processes, has rarely been taken into account in regional slope stability models. However, these bedrock processes can control the hydrological response of catchments to a large extent [Onda et al., 2001] and may be useful indicators of landslide susceptibility [Wilson \& Dietrich, 1987; Kosugi et al., 2006; Onda et al., 2004]. Thus, the assumption of a nearly impermeable soil-bedrock interface as a model boundary may lead to large errors in simulating pore water pressure development in slopes [Ebel et al., 2007; Tromp-van Meerveld and Weiler, 2008]. It is most likely the rule rather than the exception that bedrock is not fully impermeable [McDonnell, 2003] and that groundwater flow through fractured bedrock is an important process [Haught and Tromp-van Meerveld, 2011]. The bedrock may act as a sink or as a source for groundwater dynamics in the soil layer, depending on the hydraulic conductivity of the lithology, the degree of fracturing and weathering, the presence of macropores, the hydraulic head and degree of saturation. Weathered bedrock layers and bedrock fractures can provide avenues for rapid saturated flow and bedrock infiltration-exfiltration processes [Montgomery et al., 1997; Onda et al., 2004; Anderson et al., 1997]. Bedrock exfiltration is strongly controlled by shortterm and long-term precipitation duration and intensities [Uchida et al., 2003]. Consequently, large storms in combination with wet antecedent conditions are highly critical in 
forcing water to emerge from bedrock [Uchida et al., 2002].

[3] Shallow groundwater flow in fractured bedrock can lead to upward seepage and increased pore water pressure in the soil layer around the bedrock springs, while shallow confined aquifers in permeable bedrock can induce excess pore pressures. Both processes may result in localized slope failure [Everett, 1979; Mathewson et al., 1990; Montgomery et al., 2002]. Thus, bedrock infiltration and exfiltration processes influence the triggering of landslides and determine landslide intensity, volume, and runout distance [Onda et al., 2004; Matsushi and Matsukura, 2007; Katsura et al., 2008].

[4] Bedrock outbursts at several locations in Switzerland during the heavy storm events of August 2000 and August 2005 [Rickli et al., 2008] are good examples of this process. Extreme pore water pressures in the soil and bedrock during these precipitation events caused temporary artesian groundwater that gushed out as fountains along the slopes. Subsequently, landslides were triggered by groundwater flowing out of the bedrock [Berwert-Lopes and Spichtig, 2006; Liniger, 2006].

[5] These examples, as well as other landslide studies [Bonzanigo et al., 2001], show that knowledge about groundwater flow paths in the bedrock and bedrock exfiltration processes is essential to predict the likelihood of landslides occurring.

[6] Temporary springs issuing from bedrock in fresh landslide scarps are major indicators of flow through bedrock fractures [Johnson and Sitar, 1990; Calcaterra and Santo, 2004]. However, heterogeneities in the landslide hydraulic conductivity and architecture cause difficulties in tracing the origin and flow paths of groundwater in landslides. Preferential flow paths and local formation of confined and perched aquifers complicate the hydrogeology of a landslide [Debieche et al., 2011]. As a consequence, the hydrological processes triggering landslides are often not well understood.

[7] This research intends to provide a better insight into the above mechanisms. A field study was set up in central Switzerland to investigate the processes associated with the emergence of excess pore water pressure in bedrock fractures and through upward-directed groundwater flow at a location where shallow landslides occur.

\section{Site Description}

[8] Rufiberg is located in Central Switzerland to the east of Lake Zug. The mean annual precipitation in this area is $1500 \mathrm{~mm}$ of which approximately one third falls as snow. In the past, this site has been frequently affected by shallow landslides triggered by high-intensity, long-duration precipitation (Figure 1). For example, a storm in August 2005 with rain intensities exceeding $100 \mathrm{~mm}$ in $48 \mathrm{~h}$ [Bezzola and Hegg, 2007] triggered over 30 shallow landslides at Rufiberg (Figure 1).

[9] Tectonically, the Rufiberg belongs to the RigiRossberg nappe, which is part of the subalpine Molasse that was thrust toward NW over more distal Molasse, and subsequently dips $20-30^{\circ}$ toward SE. The Rigi-Rossberg nappe is composed of a succession of thick conglomerate units interbedded with marlstone and sandstone from the
Lower Freshwater Molasse (Figure 2). At the SE facing Rossberg, the sediment layers are oriented approximately parallel to the hillslope, whereas they dip into the slope on the NW facing Rufiberg. The sediment layers can be identified in the field by means of the competent conglomerate beds that form steps and vertical rock walls in the landscape (Figures 1 and 3). On the Rossberg hillside, the weathered marlstone beds act as sliding surfaces for landslides, for example, in the 1806-Goldau rockslide [Berner, 2004] (Figure 1). The conglomerate banks are intersected by numerous mainly vertically dipping joints and fractures, which can be seen in nearby outcrops (Figure 2). Infiltration of water into the joints after snowmelt and heavy rainfall causes pore water pressures to build up, which was described as the main triggering mechanism of the Goldau rockslide [Berner, 2004]. We hypothesize that hillside water flow through shallow joints and fractures in the bedrock at the Rufiberg promotes the triggering of landslides, even though the geological layering is less critical in terms of slope stability than at the Rossberg.

[10] The hydrogeological investigations presented in this paper were carried out on a steep meadow $1175 \mathrm{~m}$ above sea level (Figure 3). The mean and maximum slope angle of the test site is $25^{\circ}$ and $35^{\circ}$, respectively, and the soil layer is $1-2 \mathrm{~m}$ thick. Small springs and hydrophilic plants, such as sedges, Juncus effusus, Juncus inflexus, Ranunculus, and Pimpinella, indicate that the area is very humid.

\section{Methods}

\subsection{Electrical Resistivity Tomography}

[11] Electrical resistivity tomography (ERT) is a geophysical technique for exploring subsurface structures and groundwater by transmitting a direct current between an electrode pair and measuring the electrical potential between another electrode pair in order to determine the electrical resistivity of the underground [Daily et al., 1992]. ERT profiling at Rufiberg was used to (i) image the lithological boundaries between the marlstone and the conglomerate-sandstone beds and (ii) determine the thickness of the soil layer at the test site. A $200 \mathrm{~m}$ and a $70 \mathrm{~m}$ long ERT profile, each with 48 electrodes, were recorded along the fall line of the slope (Figure 3) in late-winter 2010, shortly before snow melt. The Wenner-Schlumberger configuration was used to record vertical and horizontal structures [Loke, 2013], and the data inversion was performed with the software Res2Dinv 3.55 (www.landviser. net; February 2013).

\subsection{Soil Properties}

[12] Samples were collected to analyze soil properties from the test site (Figure 3) in August 2010. Five undisturbed samples were collected to obtain the saturated hydraulic conductivity from oedometer tests by pushing thinwalled steel tubes $100 \mathrm{~mm}$ in diameter, $140 \mathrm{~mm}$ in length into the bottom of an excavated trench at each sampling point (top of sampling tube at 7,24,64,104, and $152 \mathrm{~cm}$ depth, respectively) and subsequently digging them out. Laboratory specimens were trimmed from the samples, which were then saturated in the laboratory and vertically step loaded and unloaded to a maximum of $800 \mathrm{kPa}$ in a 56 $\mathrm{mm}$ diameter, $20 \mathrm{~mm}$ deep oedometer ring. The settlement 


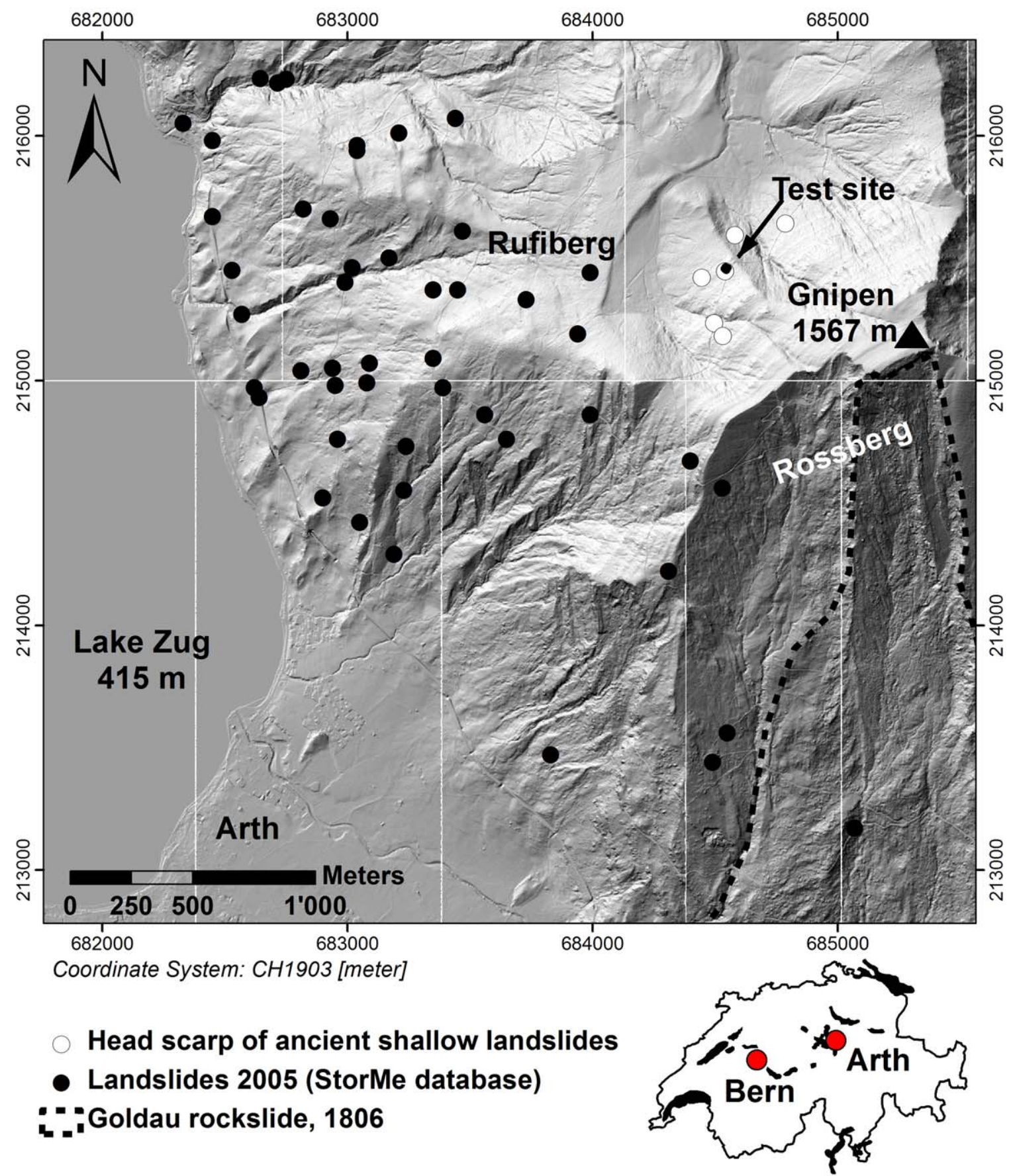

Figure 1. Digital terrain model of the investigation area (2m-DTMAV; Swisstopo, 2008). Head scarps of landslides triggered during a heavy rainfall event in August 2005 are indicated with black dots (from database of natural hazard damages StorMe, Federal Office of Environment, 2008). Head scarps of ancient shallow landslides mapped around the test site in 2010 are indicated with white dots. The limit of the Rossberg rockslide is indicated.

of the soil was recorded at each load step, and the results analyzed using the settlement-log-time method [Fratta et al., 2007] to determine the coefficient of consolidation, $c_{v}$, and the constrained stiffness modulus, $M_{E}$, from which the hydraulic conductivity can be deduced using the following equations:

$$
c_{v}=\frac{T \cdot H_{d 50}^{2}}{t_{50}}
$$

where $c_{v}$ is the coefficient of consolidation $\left(\mathrm{m}^{2} / \mathrm{s}\right), T$ is the dimensionless time factor at $50 \%$ primary consolidation $(0.197), t_{50}$ is the time corresponding to $50 \%$ primary consolidation (s), and $H_{d 50}$ is the length of the drainage path at $50 \%$ consolidation $(\mathrm{m})$. 

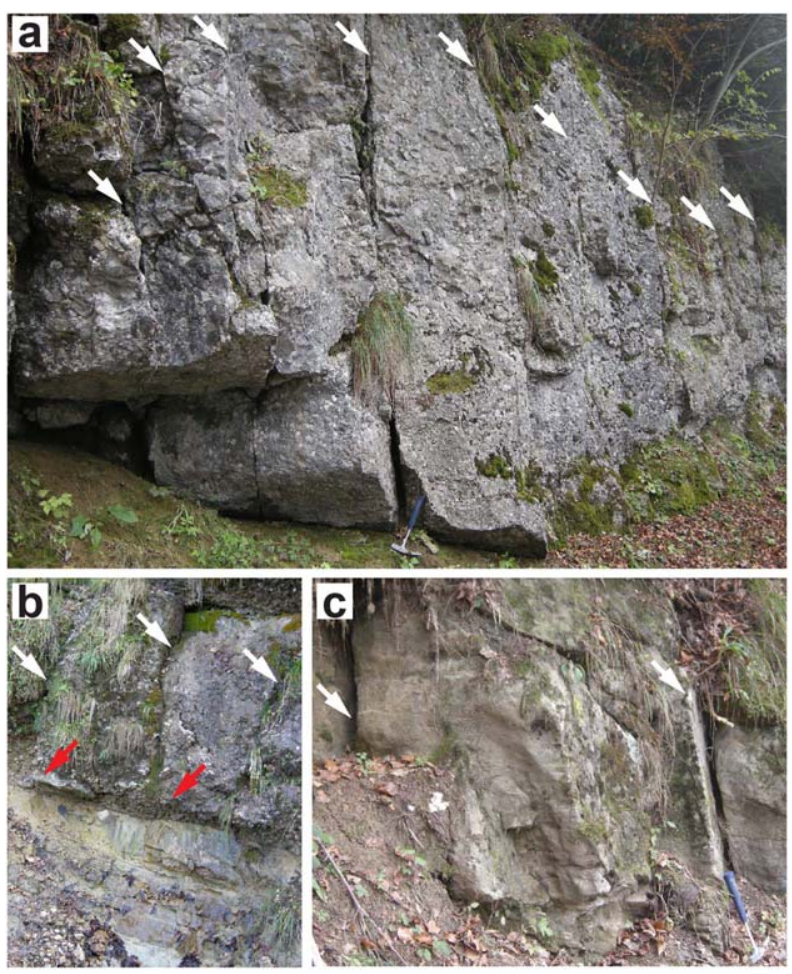

Figure 2. Photographs of the three lithologies found along the forest road above the test site showing joints (indicated with white arrows): (a) conglomerate, the aperture of joints is several centimeters, (b) colored marlstone underlying fractured conglomerate. Water is seeping out of joints in the conglomerate (red arrows), and (c) fractured sandstone.

where $K$ is the hydraulic conductivity $(\mathrm{m} / \mathrm{s}), M_{E}$ is the confined stiffness modulus $\left(\mathrm{kN} / \mathrm{m}^{2}\right)$, and $\gamma_{w}$ is the unit weight of water $\left(\mathrm{kN} / \mathrm{m}^{3}\right)$.

$$
M_{E}=\Delta \sigma_{z}^{\prime} / \Delta \varepsilon_{z}
$$

where $\Delta \sigma_{z}^{\prime}$ is the vertical effective stress increment, and $\Delta \varepsilon_{z}$ is the corresponding vertical strain increment.

\subsection{Soil Moisture Measurements}

[13] Four test pits were excavated in summer 2010 along the slope to install vertical profiles of Time Domain Reflectometry sensors [Topp et al., 1980] to measure soil water content at depths of $0.25,0.7,1.1$, and $1.5 \mathrm{~m}$ (Figure 3). The $15 \mathrm{~cm}$ long TDR rods were inserted horizontally into the vertical walls of the pits, and the four pits were carefully refilled with the excavated soil. The water content was recorded from summer 2010 to fall 2011 at $10 \mathrm{~min}$ time intervals using a Campbell TDR 100 system (Campbell Scientific, Logan, Utah, USA).

\subsection{Boreholes and Water Pressure Sensors}

[14] We drilled six boreholes in two clusters along the ERT transect (Table 1 and Figure 4). The boreholes reached a depth between 2 and $9 \mathrm{~m}$ below the ground surface. The lower half of boreholes BH1 and BH6 were cored with a $9 \mathrm{~cm}$ diameter rotational diamond drilling head. The other boreholes were drilled destructively with an $11 \mathrm{~cm}$ diameter Mitsubishi hammer system. Open standpipe piezometers were installed in boreholes $\mathrm{BH} 1, \mathrm{BH} 2$, and $\mathrm{BH} 5$ by equipping them with 1 or 2 inch-PVC tubes, whereas $\mathrm{BH} 3, \mathrm{BH} 4$, and $\mathrm{BH} 6$ were equipped with a special piezometer system composed of an enclosed measuring cell at the bottom of a 1 inch-PVC tube. Open standpipe piezometers are used to measure the free groundwater level in rather permeable lithologies, whereas an enclosed measuring cell allows the hydraulic pressure of lithologies with low permeability to be measured directly. The pressure sensor in this system is installed in an enclosed measuring cell in the sealed lower part of the piezometer and thus is not in contact with the air. Two piezometers were installed in BH6 at different depths, one in the lower soil layer and one reaching the bedrock. The PVC tubes were slotted at the bottom for $0.5,1$, or $2 \mathrm{~m}$, and the boreholes were sealed carefully with clay pellets above this filter section to avoid by pass and infiltration from the surface. DCX-22 pressure sensors from Keller AG, Winterthur, with integrated data loggers, were installed in each piezometer to measure the relative hydraulic pressure at a $30 \mathrm{~min}$ intervals from November 2010 to November 2011. The data were corrected for in situ air-pressure fluctuations.

[15] Falling head infiltration tests were performed in boreholes $\mathrm{BH} 1$ and $\mathrm{BH} 3$ to calculate the hydraulic conductivity of the conglomerate and the soil layer, respectively. The piezometer pipe was filled with water to a prescribed height and the falling water level was measured in 1 and 30 min time steps, respectively. The saturated hydraulic conductivity was then calculated according to the inversed auger-hole method described by Oosterbaan and Nijland [1994].

\subsection{Precipitation}

[16] The precipitation data used in this study were provided by the Swiss Federal Office of Meteorology and Climatology, MeteoSwiss, from the climate station in Cham/ $\mathrm{ZG}, 12 \mathrm{~km}$ to the NW of our test site. We used these data to delimit different critical rain events. A new event was defined if (i) the maximum precipitation intensity was higher than $2 \mathrm{~mm} / \mathrm{h}$ and (ii) the boreholes were drained completely before the next event started. In total, we observed 32 rain events from November 2010 to November 2011. The year under investigation was rather dry, with approximately 30\% less precipitation than the long-term average. May and July were the wettest months, with total rainfall of 100 and $170 \mathrm{~mm}$, respectively, and a maximum intensity of $22 \mathrm{~mm} / \mathrm{h}$.

\subsection{Sprinkling Experiments}

[17] Two sprinkling experiments were carried out on the test site to investigate infiltration and water flow in the soil layer [Schneider et al., 2013]. A $10 \times 10 \mathrm{~m}$ surface area (Figure 3) was irrigated for 3 and $4 \mathrm{~h}$, respectively, on 3 August (event 21) and 6 October 2011 (event 30). A total amount of 65 and $82 \mathrm{~mm}$ was sprinkled with intensities ranging between 20 and $25 \mathrm{~mm} / \mathrm{h}$. In addition, a third irrigation event was conducted in November 2011 using a Brilliant Blue solution (concentration $6 \mathrm{mg} / \mathrm{L}$ ), a water soluble, weakly soil-adsorbing dye tracer [Flury and 


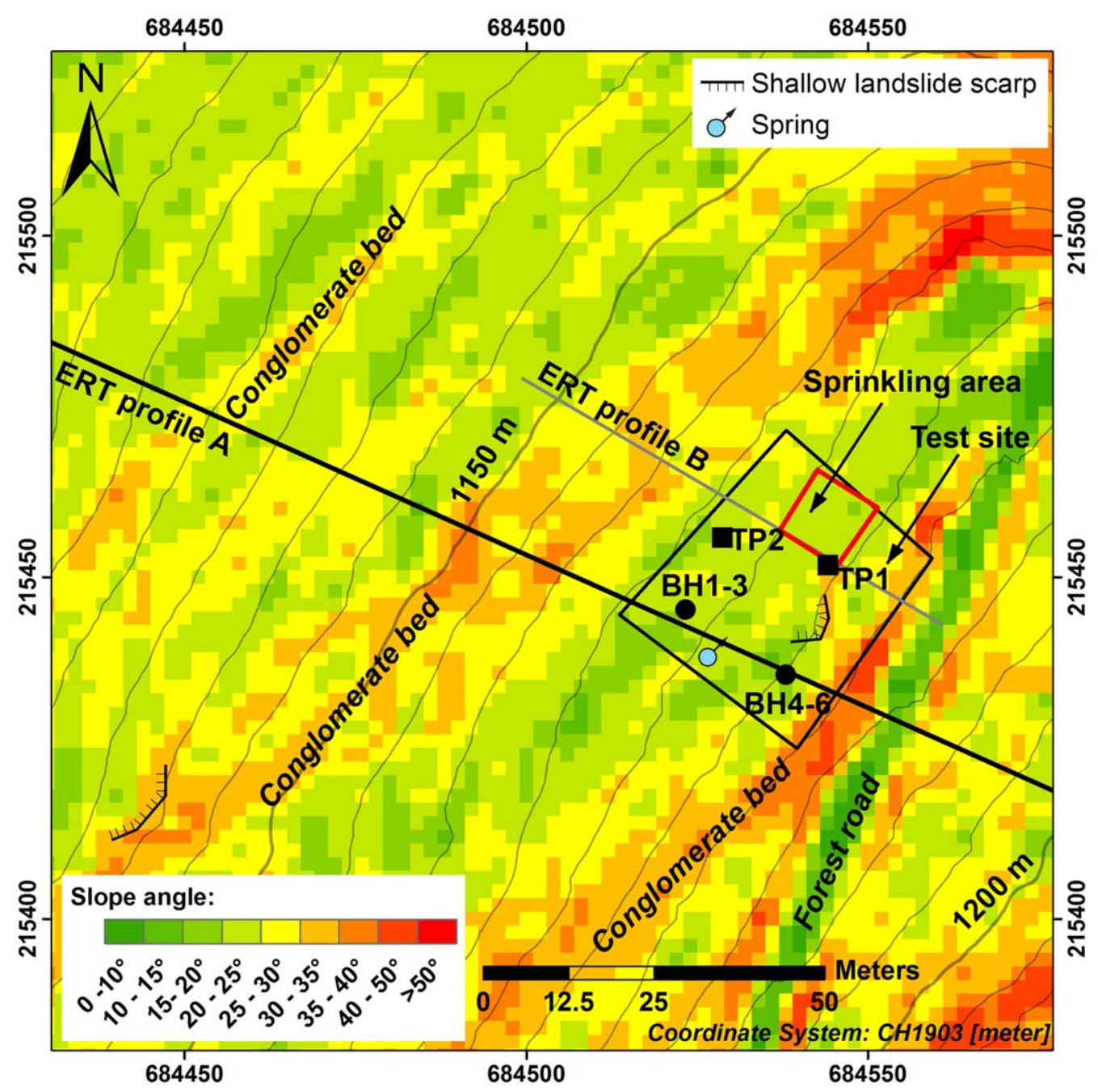

Figure 3. Map showing the test site with locations of ERT profiles, borehole clusters (BH1-3 and BH4-6), TDR pits (TP1 and TP2), and sprinkling area. The slope angle is indicated in color. The steep beds (red) oriented NE to SW represent the relatively weathering-resistant conglomerate beds. Furthermore, two landslide scarps, seeping water (spring), and the forest road are indicated.

Flühler, 1994]. In this case, we irrigated an area of $1.5 \mathrm{~m} \times$ $4 \mathrm{~m}$ for $2 \mathrm{~h}$ with an intensity of $20 \mathrm{~mm} / \mathrm{h}$.

\section{Results}

\subsection{Characterization of the Soil Layer}

[18] The soil layer at Rufiberg is classified as medium plastic clay (CM) according to the USCS and SN 670008 classifications and as Calcareous Gleysol according to
Food and Agriculture Organization [1988]. The H/Ahhorizon (according to the DIN 4220 classification [Eckelmann et al., 2005]) extends to $\sim 30 \mathrm{~cm}$ depth and lies over a layer containing orange-colored mottles that provide evidence of oxidation (Go(r)-horizon). At $>0.5 \mathrm{~m}$ depth, a gray-bluish colored layer points to reduction processes (Grhorizon). The carbonate boundary lies at $\sim 1 \mathrm{~m}$ depth, indicating that the zone below this boundary is permanently saturated. The amount of illite and smectite, which are

Table 1. Depth of Pressure Transducer and Piezometer Installed in Each Borehole

\begin{tabular}{lccc}
\hline Location & Borehole Name & Depth of Sensor (and Piezometer) & Monitoring System (Diameter) \\
\hline Cluster 1 & BH1 & $9 \mathrm{~m}$ & Open piezometer (2 inch) \\
& BH2 & $5.5 \mathrm{~m}$ & Open piezometer (2 inch) \\
BH3 & Enclosed measuring cell (1 inch) \\
Cluster 2 & BH4 & $1.7 \mathrm{~m}(2.2 \mathrm{~m})$ & Enclosed measuring cell (1 inch) \\
& BH6 & $4.4 \mathrm{~m}(4.9 \mathrm{~m})$ & Open piezometer (1 inch) \\
& & $7.8 \mathrm{~m}$ & Enclosed measuring cell (1 inch) \\
& & $1.3 \mathrm{~m}(1.8 \mathrm{~m})$ & Enclosed measuring cell (1 inch) \\
\hline
\end{tabular}


BRÖNNIMANN ET AL.: BEDROCK EXFILTRATION: SHALLOW LANDSLIDE TRIGGERING MECHANISM

Table 2. Soil Properties Measured on Samples From the Rufiberg Slope at Different Soil Depths [Maries, 2011]

\begin{tabular}{lcccccc}
\hline Depth $(\mathrm{cm})$ & Sand and Gravel (\%) & Silt (\%) & Clay (\%) & Plasticity Index (\%) & Total Porosity (\%) & Hydraulic Conductivity $k_{\text {sat }}(\mathrm{m} / \mathrm{s})$ \\
\hline $7-16$ & 38 & 42 & 20 & & 36 & \\
$24-38$ & 18 & 74 & 8 & 15 & 36 & $1.50 \mathrm{E}-10$ \\
$64-78$ & 14 & 61 & 25 & 21 & 31 & $2.20 \mathrm{E}-10$ \\
$104-118$ & 2 & 63 & 35 & 26 & 39 & $6.90 \mathrm{E}-10$ \\
$152-166$ & 0 & 66 & 34 & 23 & 36 & $6.60 \mathrm{E}-10$ \\
\hline
\end{tabular}

typical clay minerals in Molasse rocks, increases with soil depth up to 40 weight $\%$. The sand and gravel fraction decreases accordingly with depth.

[19] The saturated vertical hydraulic conductivity is very low (between $10^{-9}$ and $10^{-10} \mathrm{~m} / \mathrm{s}$ ) without any obvious trends with depth [Maries, 2011] (Table 2). This result of oedometer measurements (section 3.2) agrees with values of saturated hydraulic conductivity of approximately $10^{-10} \mathrm{~m} / \mathrm{s}$ determined in boreholes $\mathrm{BH} 3$ and BH6 using the inversed auger-hole method [Oosterbaan and Nijland, 1994]. Further evidence of very low hydraulic conductivity in the soil layer was received from the third sprinkling experiment with Brilliant Blue that was carried out in November 2011 [Schneider et al., 2013]. Excavation of the irrigated plot after two days revealed that almost no dyed water had infiltrated into the soil below $50 \mathrm{~cm}$ depth, and no lateral preferential flow paths that typically develop in clay soils along roots or fissures could be identified. Clear evidence from different sources of information confirmed that the hydraulic conductivity of the soil layer (below $30 \mathrm{~cm}$ depth) at the test site is exceptionally low.

\subsection{Geological Model}

[20] The 1-2 m thick soil layer and a succession of conglomerate, sandstone, and marlstone layers, dipping approximately $30^{\circ}$ into the slope, were detected from the borehole profiles and the two ERT sections (Figure 4). The electrical resistivity of the soil layer varies between $\sim 50$ and $500 \Omega \mathrm{m}$. Cores from boreholes BH1 and BH6 confirmed the transition between this soil layer and the weathered marlstone occurred at a depth of approximately $2 \mathrm{~m}$.

[21] Three zones of high electrical resistivity (200-1000 $\Omega \mathrm{m})$ coincide with the steep parts of the slope (Figure 3) and are interpreted as conglomerate beds associated with sandstone, dipping $\sim 30^{\circ}$ into the slope. Sandstone and conglomerate are hard rocks and therefore are stable as steep layers in the landscape. The electrical resistivity for sandstone and conglomerate is typically $100-1000 \Omega \mathrm{m}$ and $>1000 \Omega \mathrm{m}$, respectively [Palacky, 1987]. A very competent conglomerate-sandstone layer was found in borehole $\mathrm{BH} 1$ between 7.5 and $9 \mathrm{~m}$ depth. A very hard layer was detected at the bottom of $\mathrm{BH} 5$ and $\mathrm{BH} 6$, most likely representing another conglomerate-sandstone layer.

[22] The slope is less steep between the three high resistivity zones identified, and the electrical resistivity varies between 40 and $100 \Omega \mathrm{m}$, indicating marlstone beds. The electrical resistivity of marlstone is typically $<100 \Omega \mathrm{m}$ [Palacky, 1987]. Marlstone is easily weathered and thus the slope is generally flatter than along the conglomerate bands. Boreholes $\mathrm{BH} 2, \mathrm{BH} 4, \mathrm{BH} 5$, and $\mathrm{BH} 6$ were drilled in the weathered marlstone. The drilled cores from BH1 and $\mathrm{BH} 6$ revealed weathered and weak marlstone that eas- ily broke along numerous red-brown fissures. These weathered and colored fissures indicate that transient groundwater has been present in the bedrock.

\subsection{Dynamics of Water in the Soil Layer}

[23] Information about the seasonal and short-term fluctuations of water content and groundwater level of the soil layer was received from the two boreholes BH3 (sensor at $1.7 \mathrm{~m}$ depth) and BH6 (sensor at $1.3 \mathrm{~m}$ depth), as well as from the TDR profiles (Figures 5 and 6). The groundwater level in BH 3 varied between 1.0 and $1.7 \mathrm{~m}$ depth. A temporary water table was observed in BH6 only from November 2010 to mid-January 2011 and in March 2011 and did not show immediate response to rainfall. The groundwater level was below the level of the sensor outside these periods.

[24] The TDR sensor in test pit 1 at $1.5 \mathrm{~m}$ depth and the three lower sensors in test pit 2 at $1.5-0.7 \mathrm{~m}$ depth indicated permanently high water contents and did not respond to the rainfall events in August and October 2011 (Figure 5). Most likely, these TDR sensors were located in a soil layer that was permanently saturated (or close to saturation, Gr-horizon). The two TDR sensors at 0.7 and $1.1 \mathrm{~m}$ depth in test pit 1 reacted weakly (with an increase of $2-5 \% \mathrm{vol}$ ) to intense rainfall (Figure 5). These sensors were most likely in the Go(r) horizon, which was usually unsaturated. Only the top-most sensors $(0.25 \mathrm{~m}$ depth) in both pits did respond clearly and dynamically to rainfall and sprinkling. For example, an increase in water content of up to $10 \%$ was observed after the start of the sprinkling experiment (Figure 3). After rainfall, the top-most sensors exhibited higher water contents for several hours, whereas the intermediate sensors indicated higher volumetric water content for days. Overall, the TDR measurements confirm that the uppermost $\sim 25 \mathrm{~cm}$ of the soil profile are more permeable than the intermediate soil layer ( $>0.5 \mathrm{~m}$ depth), eventually leading to lateral subsurface runoff in the top layer $(\mathrm{H} / \mathrm{Ah}$ horizon). The dye tracer experiment mentioned in section 4.1 provided visual evidence for this [Schneider et al., 2013].

\subsection{Response of Bedrock Groundwater to Rainfall}

[25] The pressure measurements in the 4-9 $\mathrm{m}$ deep boreholes reflect the groundwater response of the bedrock to rainfall. Boreholes $\mathrm{BH} 2$ and $\mathrm{BH} 4$ were drilled into the weathered marlstone ( $\sim 2$ to $5 \mathrm{~m}$ depth), whereas boreholes $\mathrm{BH} 1, \mathrm{BH} 5$, and $\mathrm{BH} 6$ hit fissured conglomerate layers. The water level in the deepest borehole BH1 always remained constant at $7.5 \mathrm{~m}$ depth. The water level did not change in this borehole even during a falling head infiltration test, suggesting that a fracture in the bedrock drained the piezometer at this specific depth. No groundwater was found in $\mathrm{BH} 2$ during the entire measuring period, whereas 

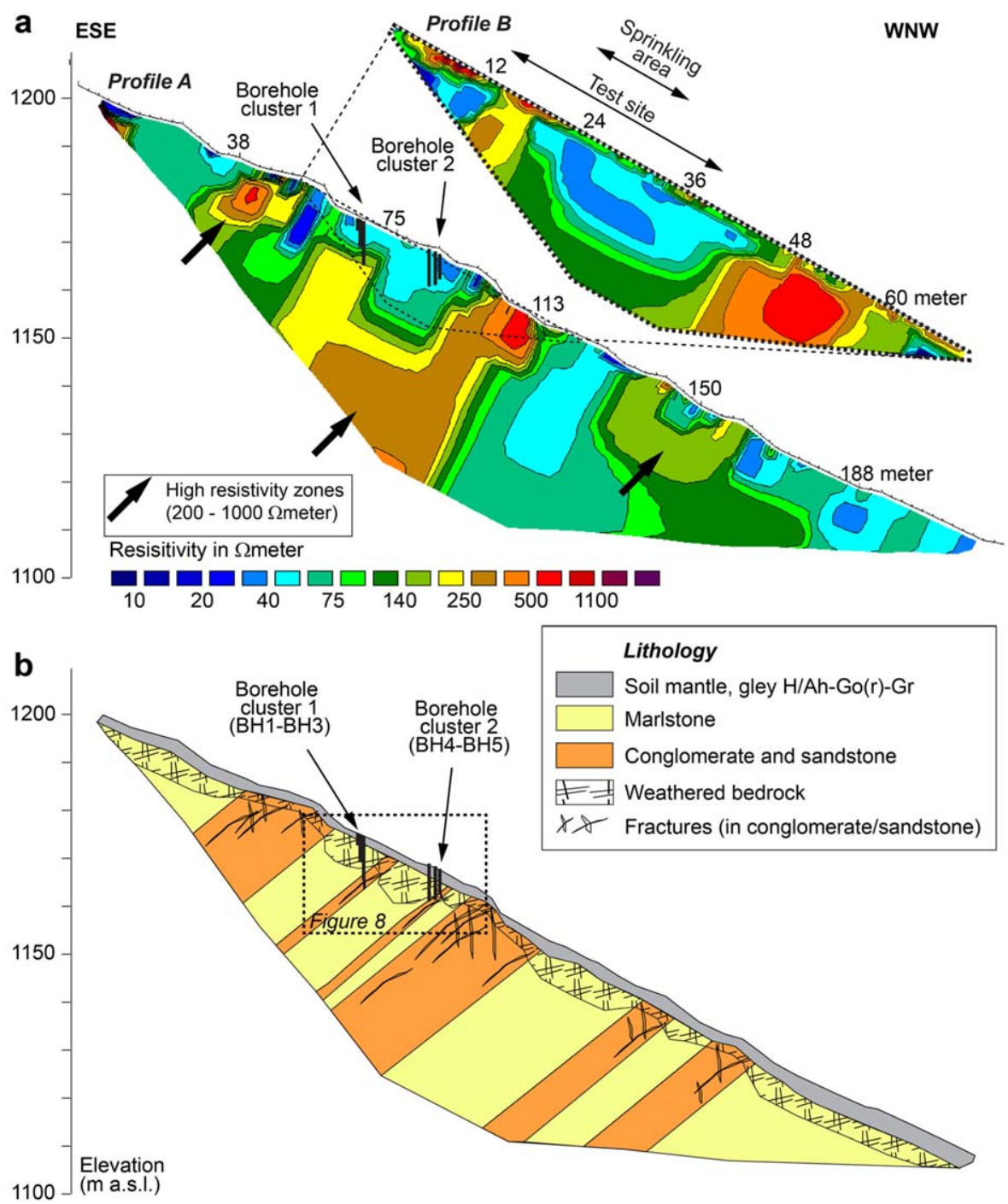

Figure 4. (a) Long (profile A) and short (profile B) ERT profiles recorded along the upper part of the Rufiberg slope on 19 March 2010 and (b) geological interpretation. The locations of the boreholes are indicated.

significant water pressure fluctuations were registered in cluster 2 in $\mathrm{BH} 4, \mathrm{BH} 5$, and BH6 (Figures 5 and 6). The water pressure in $\mathrm{BH} 5$ and $\mathrm{BH} 6$, which were drilled into the same conglomerate layer, were similar and confirmed the consistency of these measurements. The groundwater pressure response in the weathered marlstone layer in BH4 deviated from the pressure response in the two deeper boreholes. Overall, we observed three different response types of the pressure measurements to rainfall, snowmelt, or irrigation.

\subsubsection{Response Type 1}

[26] No groundwater response was measured in the weathered marlstone (BH4) (Figure 5) during both minor rainfall and the sprinkling experiments. The hydraulic head in the conglomerate (BH5 and $\mathrm{BH} 6$ ) remained below or just reached that of BH4. Three hours after the start of the irrigation experiments, the water pressure rose rapidly in the fractured conglomerate (BH5 and $\mathrm{BH} 6)$, which was several hours earlier than the response in the H/Ah-horizon of test pit 2. The sharp sprinkling-induced pressure differs from natural events, as the rising and falling sections of the water pressure-time-curves are almost linear and the bedrock fractures filled and drained faster than during natural rainfall events (Figure 7).

\subsubsection{Response Type 2}

[27] The water pressure in the weathered marlstone (BH4) increased by a few centimeters during snowmelt or minor rainfall. The snowmelt in March 2011 (Figure 6, event 5) provided a good example of this response. Daily pressure peaks were measured from 13 to 16 March only in the conglomerate layer between 16:00 and 20:00 h and indicated snowmelt infiltration into the bedrock fractures. These peaks did not reach the level of the total head in BH4 (Figure 7a).

\subsubsection{Response Type 3}

[28] The water pressure in the fractured conglomerate (BH5 and BH6) increased rapidly on average $0.7 \mathrm{~m}$ per hour (event 9 in Figure 6 and Figure 7b) for heavy rainfall with intensities larger than $2 \mathrm{~mm}$ per hour and a total sum of at least $15 \mathrm{~mm}$. The maximum pressure level measured 

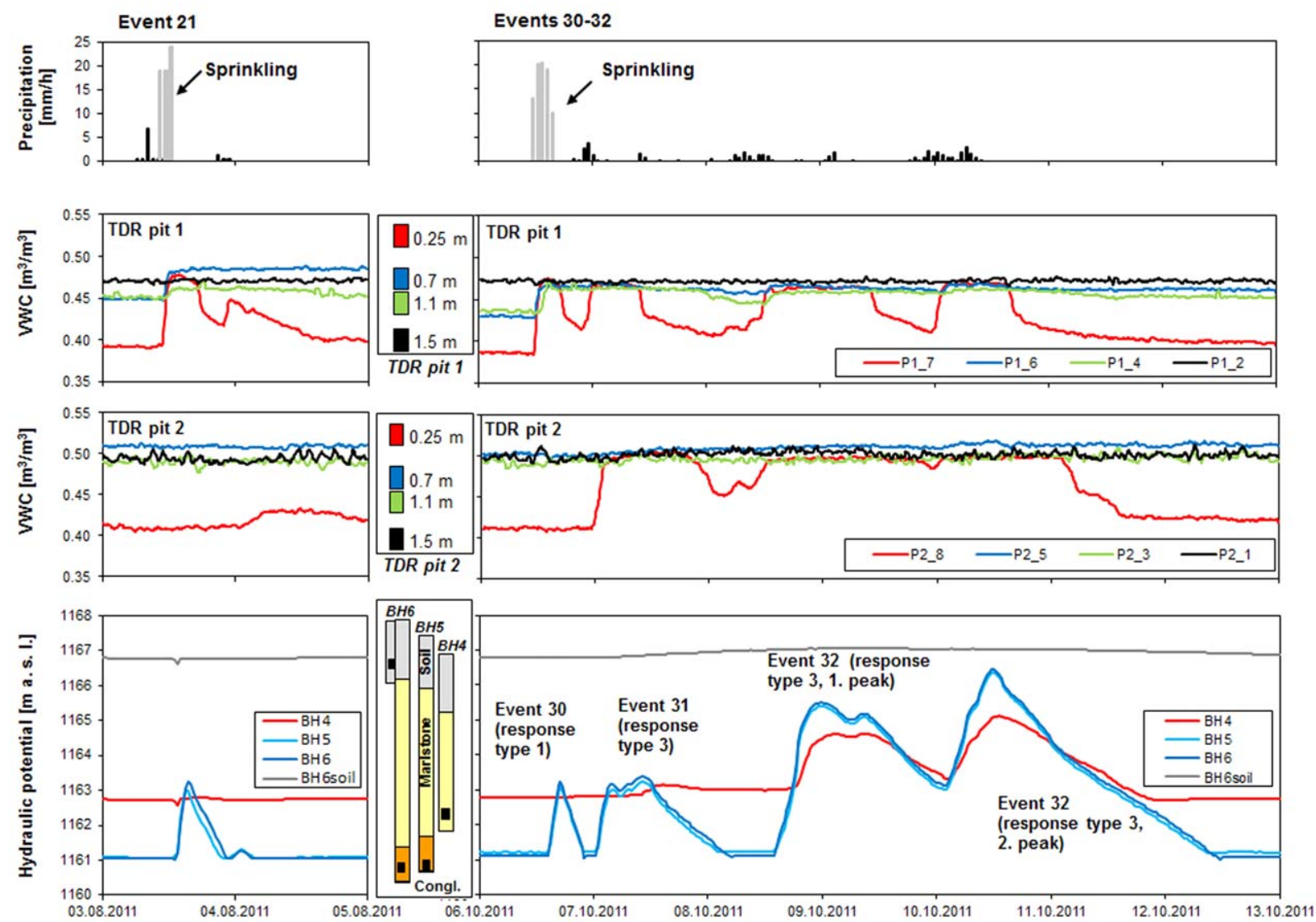

Figure 5. Hourly rain intensity at Cham/ZG, volumetric water content (VWC) measured in TDR pit 1 and 2 at Rufiberg, and hydraulic potential monitored in boreholes BH4 to BH6 in cluster 2 during precipitation events 21 (June 2011) and 30-32 (October 2011). Events 21 and 30 were irrigation experiments carried out in the vicinity of the boreholes and represent examples for response type 1, whereas events 31 and 32 are examples for response type 3.
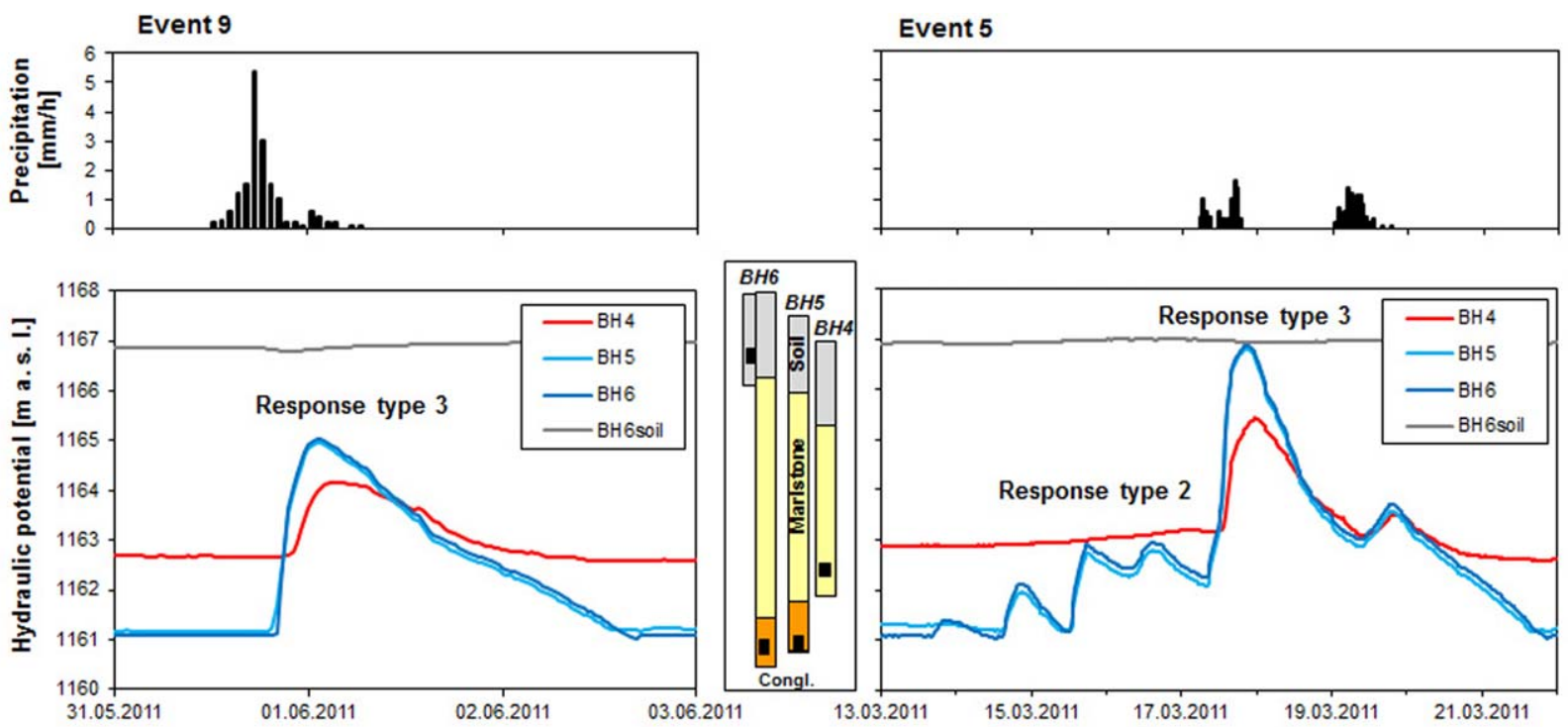

Figure 6. Hourly rain intensity at Cham/ZG and hydraulic potential monitored in BH4 to BH6 in cluster 2 at Rufiberg during precipitation events 9 (May 2011) and 5 (March 2011). Event 9 is an example for a common occurrence, whereas event 5 is an example for snow melt that preceded/coincided with rainfall. 
a)

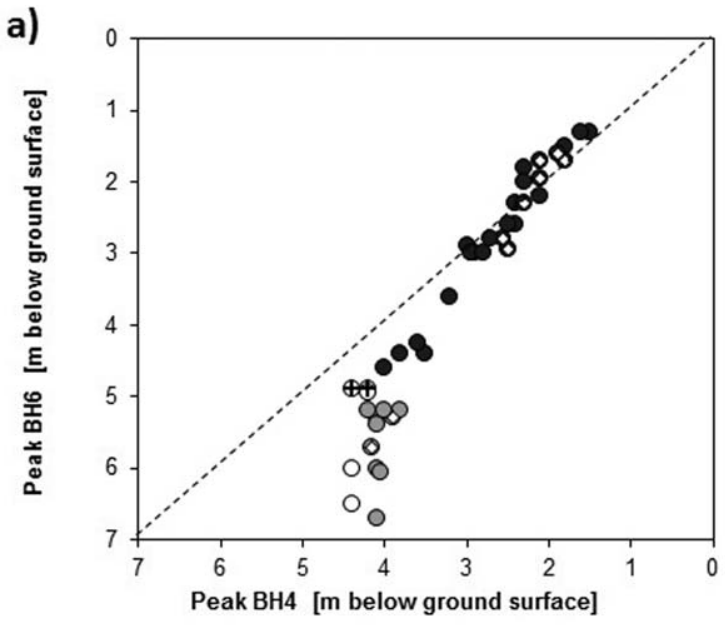

b)

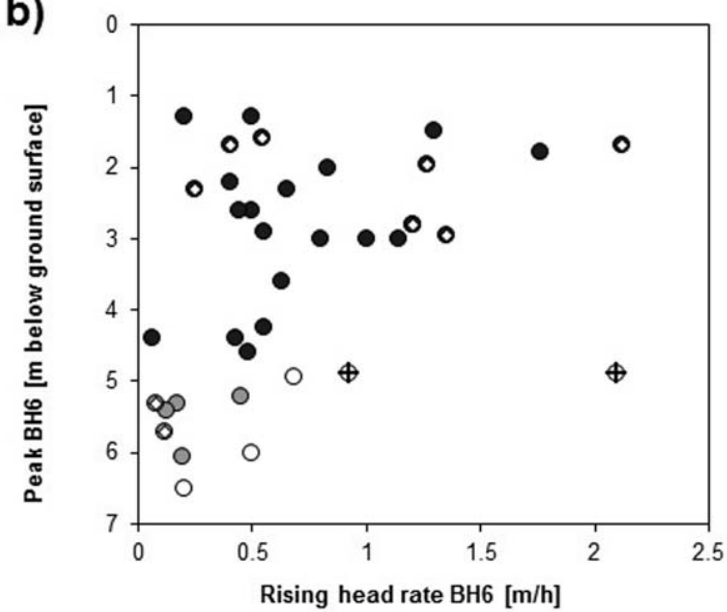

OResponse type 1

OResponse type 2

- Response type 3

+Sprinkling experiment

$\diamond$ Secondary peak

Figure 7. Development of the hydraulic head for the three response types. The sprinkling experiments and secondary peaks are indicated (superimposed symbols). (a) Correlation between the peak hydraulic potential in the fissured conglomerate (BH6) and in the weathered marlstone (BH4) corrected for the surface height difference between $\mathrm{BH} 4$ and $\mathrm{BH} 6$ and (b) maximum hydraulic head in relation to the velocity of the rise in water pressure.

in $\mathrm{BH} 5$ and $\mathrm{BH} 6$ during our observation period was 0.6 and $0.8 \mathrm{~m}$ below ground surface, respectively. This was higher than the water level in the soil layer. The faster the pressure rose, the higher was the maximum pressure level, but a high pressure level did not necessarily indicate a faster rise (Figure 7b). After the hydraulic potential passed a level of $\sim 4.5 \mathrm{~m}$ below the ground surface in BH6, the water pressure in the weathered marlstone (borehole BH4) also started to rise rapidly. Probably, the two monitored geological layers are hydrologically (direct water exchange) or hydraulically (transmission of water pressure) connected only after passing this level. Figure 7 a shows that there is a linear relationship between the water level rise of the conglomerate layer (BH5 and $\mathrm{BH} 6)$ and that in the weathered marlstone (BH4). The maximum pressure level reached in the weathered marlstone was $1.5 \mathrm{~m}$ below the ground surface, thus $\sim 1 \mathrm{~m}$ lower than in the conglomerate bed relatively to the ground surface. Typical examples of response type 3 were (i) event 5 when rainfall coincided with snowmelt on 17 March (Figure 6) and (ii) events 31 and 32 with two peaks, one on 8 October and one on 10 October 2011 (Figure 5). The second peak of event 32 reached a higher level than the first peak. Secondary peaks are usually higher than primary peaks because in these cases, the bedrock is already pre-saturated due to precedent rainfall or snowmelt (Figure 6, event 5).

\section{Discussion}

\subsection{Conceptual Hydrogeological Model}

[29] From the geological model and the hydrological measurements, the following conceptual hydrogeological model can be derived for the Rufiberg site (Figure 8): The overlying soil layer has a permanently saturated horizon at a depth of $1-1.5 \mathrm{~m}$, due to low hydraulic conductivity and high water retention of the clayey soil (Figure 8a, location A). Locally, the saturated zone reaches the surface and water seeps out of the slope, for example, between the two borehole clusters (Figure 8a, location B). The impermeability of the unfractured bedrock shows up in $\mathrm{BH} 1$ where the water pressure remains constant at a level of $1.5 \mathrm{~m}$ above the sensor (Figure $8 \mathrm{a}$, location $\mathrm{C}$ ). The water pressure in the boreholes of cluster 2 responds and rises rapidly, typically 5-14 $\mathrm{h}$ after the onset of rainfall and $3 \mathrm{~h}$ after the start of the sprinkling experiments with high rainfall intensities. The fractures in the conglomerate become partly saturated during minor rainfall events or the sprinkling experiments (Figure 8a, location D), whereas no groundwater response is observed in the weathered marlstone (Figure 8a, response type 1).

[30] The water pressure in the weathered marlstone rises slowly and relatively smoothly during response type 2 (Figure $8 \mathrm{~b}$, location E) probably due to minor groundwater flow through small fissures that occur before the marlstone layer connects hydrologically or hydraulically with the conglomerate layer below.

[31] After the hydraulic pressure in BH6 exceeds a level of $\sim 4.5 \mathrm{~m}$ below the ground surface (Figure 8c, location F), BH4 also starts to respond rapidly due to groundwater flow through joints in the conglomerate, which then connect probably hydrologically, or at least hydraulically, with the marlstone (response type 3; Figure 8c, location G). During heavy rainfall or when rainfall coincides with snowmelt, the hydraulic head in the deeper bedrock (boreholes $\mathrm{BH} 5$ and $\mathrm{BH} 6$ ) rises higher than in the shallower bedrock (borehole BH4). Such a hydraulic gradient my cause uplift pressure, upward-directed water flow and localized bedrock exfiltration (Figure 8c, location $\mathrm{H}$ ). The pore water pressure rises immediately when it starts raining and reaches a higher level if the fractures in the bedrock are already saturated due to precedent precipitation or snow melt. 
a) Response type 1

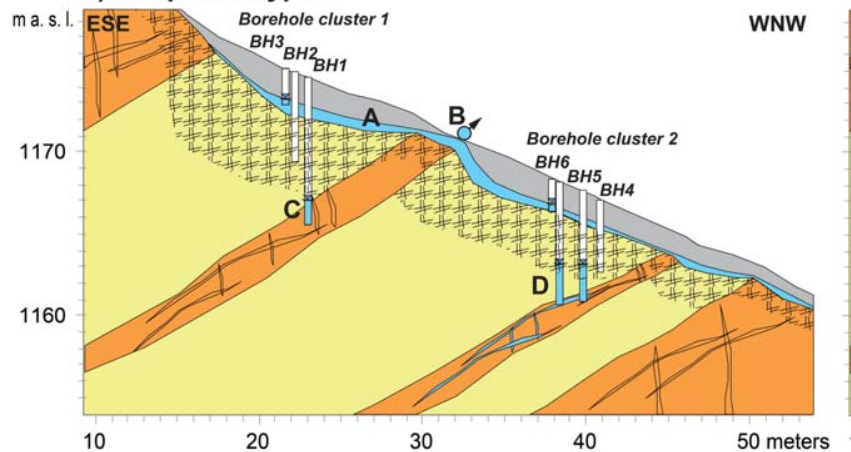

c) Response type 3

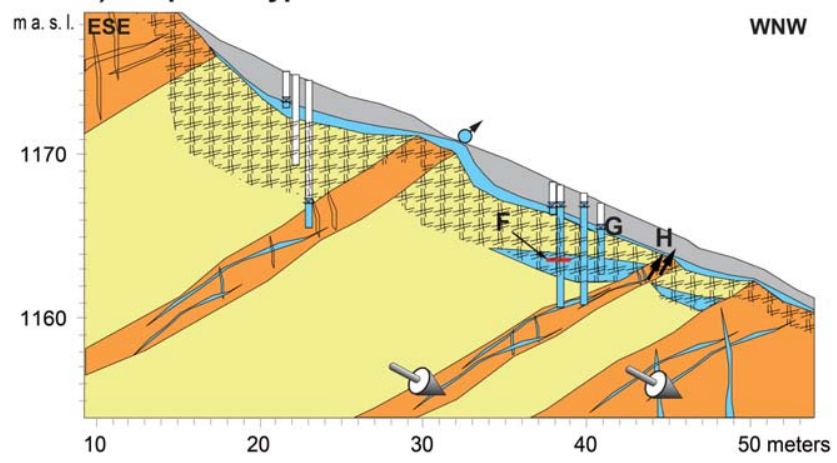

\section{b) Response type 2}

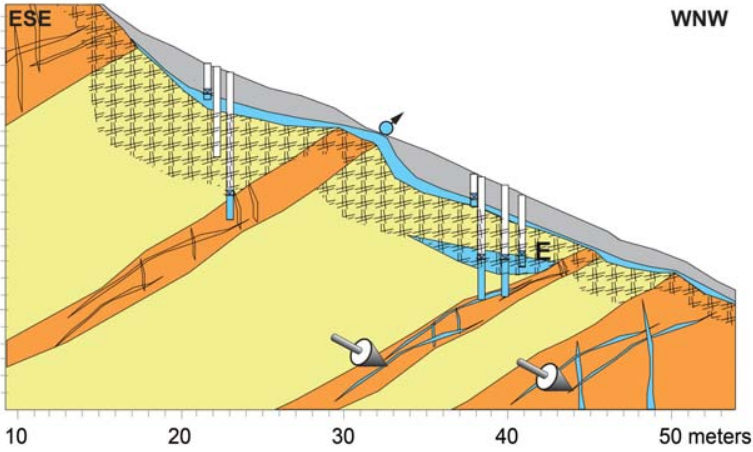

20

\section{Geology}

Soil layer (H/Ah-Go(r)-Gr)

Marlstone

Conglomerate and sandstone

Weathered bedrock

Fractures (in conglomerate and sandstone)

Hydrogeology

Saturated soil layer and bedrock

Maximum measured hydraulic potential

(2) Groundwater flow (along conglomerate bands, 3D)

1. Excess water pressure acting on soil layer

of Seepage zone

Figure 8. Conceptual hydrogeological model of the Rufiberg slope for response (a) 1, (b) 2, and (c) 3. Location A indicates the saturated G(r)-horizon; location B indicates water seeping out of the slope; location $\mathrm{C}$ indicates trapped water in $\mathrm{BH} 1$; location $\mathrm{D}$ indicates saturated bedrock fractures; location $\mathrm{E}$ indicates the sparse response in $\mathrm{BH} 4$; location $\mathrm{F}$ indicates that the hydraulic head in $\mathrm{BH} 6$ passed a level of $\sim 4 \mathrm{~m}$ below ground surface; location $\mathrm{G}$ indicates the rapidly rising hydraulic head in $\mathrm{BH} 4$; and in location $\mathrm{H}$, black arrows indicate excess water pressure. Gray arrows indicate the direction of groundwater flow laterally along the fractured conglomerate beds from NE to SW.

\subsection{Rapid Bedrock Groundwater Response in Spite of Low Permeable Soil Layer}

[32] Our water pressure measurements clearly indicated that the groundwater response to rainfall is very rapid in the bedrock. This can be explained either by fast water pressure transmission through the bedrock aquifer or by rapid groundwater flow through bedrock fractures. Both processes require two conditions: First, the hydraulic conductivity of the bedrock at Rufiberg is locally very high and/or joints and fractures are well interconnected with each other. The smaller is the volume of the waterconducting fractures, the faster is the pressure transmission through the aquifer. We have no direct measurements of saturated hydraulic conductivity in the bedrock, however, in the case of rapid groundwater flow through the bedrock, a back calculation based on the observed delay between rainfall and groundwater response leads to a maximum effective groundwater flow velocity of $10^{-3}$ to $10^{-4} \mathrm{~m} / \mathrm{s}$. Second, rainfall is rapidly transmitted through the soil layer. This is clearly contradictory to the very low permeability of the soil layer that was assessed in this work. The very low saturated hydraulic conductivity of $10^{-9}$ to $10^{-10}$ $\mathrm{m} / \mathrm{s}$ that we determined based on three independent methods is reasonable for heavy clay soils with only few indications of preferential flow paths. In order to obtain the fast response observed in the bedrock groundwater, water must have infiltrated further upslope where (i) fractured conglomerate bedrock outcrops, (ii) bedrock is directly overlaid by the permeable H/Ah horizon, or (iii) tree roots or desiccation cracks are present. Once infiltrated into the bedrock, water likely flows along the fractured conglomerate beds, which dip in a SE direction in the area of the test site.

[33] With the present geological setting, a confined aquifer may form in the bedrock below the soil layer during rain storms. We monitored this confined aquifer in $\mathrm{BH} 4$, $\mathrm{BH} 5$, and BH6 in the fractured bedrock and observed how the hydraulic heads build up quickly during rain storms. Another indication for a confined aquifer was the local water outbursts that were observed during the August 2005 storm. As a consequence of the low permeability of the soil layer, a near-surface confined aquifer with artesian groundwater pressure conditions built up in the fractured bedrock. In our investigation period, the maximum pore pressure measured in the fractured conglomerate was $0.6 \mathrm{~m}$ below the soil surface, thus higher than the groundwater level in the soil layer. In another slope study in the Oregon Coast Range [Montgomery et al., 2002, 1997], total head measured in weathered bedrock locally exceeded the elevation of upper, dry piezometer, documenting an exfiltrating gradient from the shallow bedrock to the overlying soil. Nevertheless, the groundwater response measured in the 
weathered bedrock in this watershed was not as fast as at Rufiberg, and the rise in hydraulic head was not as high. The maximum rise in hydraulic head measured in the investigated catchment of the Oregon Coast Range was 1.5 $\mathrm{m}$. This is probably because the soil layer in this catchment was generally more permeable than the bedrock, and thus it is difficult to maintain high water pressure in the weathered bedrock [Montgomery et al., 2002].

\subsection{Fracture Flow, Bedrock Exfiltration, and Shallow Landslide Triggering}

[34] At the Rufiberg, bedrock fracture flow is an important hydrogeological feature that may influence the stability of the slope. The importance of bedrock fracture flow has also been emphasized for other catchments from around the world. In the Coastal Mountains of British Columbia, for example, heavily fractured bedrock underlies the soil layer, and bedrock fractures act as efficient hydrological conduits draining the system [Laudon and Slaymaker, 1997]. In a watershed underlain by weathered granite in Japan, infiltration and exfiltration processes at the soil-bedrock interface were described as dominant hydrological runoff generation processes [Kosugi et al., 2006]. Bedrock exfiltration into the soil layer formed more than half of the annual discharge in this catchment. In another granitic watershed in Japan, semiperennial groundwater exfiltrating from deep bedrock led to presaturation of the soil layer. This facilitated an increased peak in the groundwater level in the soil layer during subsequent storm events and may increase the risk of shallow landslides [Kosugi et al., 2008].

[35] The impact of groundwater in bedrock on the triggering of landslides is complex and difficult to localize. Two processes should be distinguished with respect to landslide triggering induced by bedrock fracture flow: (i) high water pressure in the confined bedrock aquifer that exceeds the water pressure in the (low permeability) soil cover may decrease the mobilized shear strength along the landslide slip surface and (ii) an outward hydraulic gradient may cause the groundwater in bedrock fractures to exfiltrate into the soil cover causing localized bedrock springs. Shallow landslides initiate preferentially where local upward flow develops in the soil layer [Montgomery et al., 2009] as an outward oriented seepage direction is less favorable for the stability of a slope than for example slope-parallel seepage [Crosta, 1998; Iverson and Major, 1986]. Excess pore water pressure and bedrock exfiltration develop at particular locations depending on the distribution and connectivity of the near-surface bedrock fracture system [Montgomery et al., 2002]. As it is almost impossible to detect the location of bedrock fractures from the ground surface, prediction of the location and timing of shallow landslides influenced by fracture flow is a very difficult undertaking [Montgomery et al., 2009].

[36] It may be surprising that high water pressure in bedrock fractures in the upper part of the Rufiberg slope were observed as one would expect usually confined aquifers and bedrock exfiltration to occur in the lower part of a slope [Katsura et al., 2008]. The boreholes were possibly drilled in a local and rather shallow fracture system, which may respond differently to rainfall than the overall groundwater table in the mountain. Nevertheless, the geology of our test site, a succession of alternating conglomerate, sandstone, and marlstone beds dipping approximately $30^{\circ}$ toward SE is representative for the entire Rufiberg. Therefore, the rapid response in water pressure in bedrock fractures and subsequent exfiltration processes is likely to influence the triggering of shallow landslides on the majority of the slopes in the Rufiberg area. For example, it was observed that water extruded like a fountain from the slope next to the test site during the extreme rainfall event of August 2005, which triggered a large number of landslides on the Rufiberg (Figure 1). Similar observations were also reported for two other areas in Switzerland, Prättigau and Napf [Rickli et al., 2008].

[37] The comprehensive investigations reported in this paper provide a clear picture of the groundwater dynamics along the Rufiberg slope. However, the question remains open how high the water pressure in the bedrock fractures needs to rise to destabilize the slope, and what rain intensity and duration would be necessary to reach this critical pore water pressure. The rainfall intensities and sums measured in the period from November 2010 until November 2011 were far lower than the precipitation values recorded during the extreme event in August 2005. In this case, it will be necessary to consider the geometry of any likely failure mechanism, the hydraulic gradient, the unit weight of the ground, and the interface friction between the bedrock and the overlying soil layer using either simple limit equilibrium approaches or coupled numerical analyses.

\section{Conclusions}

[38] The comprehensive data set from Rufiberg is one of the rare cases, where detailed geological and geophysical information is available together with continuous groundwater measurements in the soil layer and in the bedrock. This data record allowed a hydrogeological conceptual model to be developed for the test site that explains the groundwater response observed and gives evidence for the triggering of shallow landslides in the area.

[39] The importance of bedrock exfiltration as a trigger of shallow landslides has been hypothesized previously. We have shown through the hydrogeological model that the traditional surface-oriented hydrological perspective is not valid in the present geological setting. The comprehensive data set presented in this paper provides clear evidence for the formation of high water pressure in bedrock fractures that exceeds the water pressure in the overlying soil. The case study from Rufiberg suggests that short-term antecedent precipitation and saturation of the bedrock are important controls on this effect. The presence of joints and fractured outcrops, which act as preferential flow paths locally connecting the soil surface and the bedrock, is a crucial prerequisite for this mechanism. The hydraulic conductivity of the soil layer is clearly too low to allow to build up such a dynamic water table in the bedrock without preferential flow paths.

[40] The implication for numerical geomechanical landslide forecast models is that preferential bedrockinfiltration and bedrock-exfiltration cannot be disregarded for geological settings similar to Rufiberg, which are widespread in the Molasse formations in the Alps or elsewhere. Numerical hydrogeological modeling of groundwater pressure response to rainfall and snowmelt would yield the 
opportunity to discuss scenarios of potential landslide triggering. Further investigations at other test sites are needed before the relationship between bedrock exfiltration and slope stability can be stated in general terms.

[41] Acknowledgments. The authors would like to thank Gasser Felstechnik AG, Lungern for the professional drilling work, Solexperts AG, Mönchaltorf for the support with the installation of the pressure sensors, Seraina Kauer for the support on the test site, and the UnterallmendKorporation Arth for the authorization to carry out our experiments on their ground. This research was partially funded by the ETH Competence Centre for Environment and Sustainability (CCES) within the framework of the project TRAMM (Triggering of Rapid Mass Movements in Steep Terrain). Finally, we thank the editors and reviewers for their valuable comments and suggestions.

\section{References}

Anderson, S. P., W. Dietrich, D. Montgomery, R. Torres, M. Conrad, and K. Loague (1997), Subsurface flow paths in a steep, unchanneled catchment, Water Resour. Res., 33(12), 2637-2653, doi:10.1029/ 97WR02595.

Berner, C. (2004), Der Bergsturz von Goldau. Geologie, Ausbreitung und Dynamik des grössten historischen Bergsturzes der Schweiz, MS thesis, Dep. of Earth Sci., ETHZ, Zurich, Switzerland.

Berwert-Lopes, J., and F. Spichtig (2006), Unwetter 22/23 August 2005, Ereignisdokumentation, Tech. Rep. 16, Amt für Wald und Raumentwicklung Obwalden, Sarnen, Switzerland, January.

Beven, K., and P. Germann (1982), Macropores and water flow in soils, Water Resour. Res., 18, 1311-1325, doi:10.1029/WR018i005p01311.

Bezzola, G. R., and C. Hegg (2007), Ereignisanalyse Hochwasser 2005, Teil 1-Prozesse, Schäden und erste Einordnung, Tech. Rep. UmweltWissen 0707, Bundesamt für Umwelt BAFU, Bern, Switzerland, Eidgenössische Forschungsanstalt WSL, Birmensdorf, Switzerland.

Bonzanigo, E., E. Eberhardt, and S. Loew (2001), Hydromechanical factors controlling the creeping Campo Vallemaggia landslide, paper presented at UEF International Conference on Landslides - Causes, Impacts and Countermeasures, Davos, Verl. Glückauf GmbH, Essen, Germany.

Brammer, D. D., and J. McDonnell (1996), An evolving perceptual model of hillslope flow at the Miami catchment, Adv. Hillslope Processes, 1, 35-60.

Calcaterra, D., and A. Santo (2004), The January 10, 1997 Pozzano landslide, Sorrento Peninsula, Italy, Eng. Geol., 75, 181-200, doi:10.1016/ j.enggeo.2004.05.009.

Crosta, G. (1998), Regionalization of rainfall thresholds: An aid to landslide evaluation, Environ. Geol., 35(2-3), 131-145.

Daily, W., A. Ramirez, D. LaBrecque, and J. Nitao (1992) Electrical resistivity tomography of vadose water movement, Water Resour. Res., 28(5), 1429-1442, doi:10.1029/91WR03087.

Debieche, T.-H., T. A. Bogaard, V. Marc, C. Emblanch, D. M. Krzeminska, and J.-P. Malet (2011), Hydrological and hydrochemical processes observed during a large-scale infiltration experiment at Super-Sauze mudslide (France), Hydrol. Processes, 26, 2157-2170, doi:10.1002/ hyp. 7843 .

Ebel, B. A., K. Loague, J. E. Vanderkwaak, W. E. Dietrich, D. R. Montgomery, R. Torres, and S. P. Anderson (2007), Near-surface hydrologic response for a steep unchanneled catchment near Coos Bay, Oregon: 2. Physics-based simulations, Am. J. Sci., 307, 709-748, doi:10.2475/ 04.2007.03.

Eckelmann, W., H. Sponagel, W. Grottenthaler, and J.-K. Hartmann (2005), Bodenkundliche Kartieranleitung. 5. verbesserte und erweiterte Auflage, Tech. Rep., Bundesanst. für Geowissenschaften und Rohstoffe und Niedersächsisches Landesamt für Bodenforschung, Hannover, Germany.

Everett, A. G. (1979), Secondary permeability as a possible factor in the origin of debris avalanches associated with heavy rainfall, J. Hydrol., 43, 347-354.

Food and Agriculture Organization (1988), FAO/Unesco Soil Map of the World, Revised Legend, with corrections, World Soil Resour. Rep., 60, Rome.

Flury, M., and H. Flühler (1994), Brilliant Blue FCF as a dye tracer for solute transport studies-A toxicological overview, J. Environ. Qual., 23(5), 1108-1112.

Fratta, D., J. Aguettant, and L. Roussel-Smith (2007), Introduction to Soil Mechanics Laboratory Testing, CRC Press, London.
Haught, D. R. W., and H. J. Tromp-van Meerveld (2011), Spatial variation in transient water table responses: Differences between an upper and lower hillslope zone, Hydrol. Processes, 25(25), 3866-3877.

Iverson, R. M. (2000), Landslide triggering by rain infiltration, Water Resour. Res., 36(7), 1897-1910.

Iverson, R. M., and J. Major (1986), Groundwater seepage vectors and the potential for hillslope failure and debris flow mobilization, Water Resour. Res., 22(11), 1543-1548.

Johnson, K. A., and N. Sitar (1990), Hydrologic conditons leading to debris-flow initiation, Can. Geotech. J., 27, 789-801.

Katsura, S., K. Kosugi, T. Mizutani, S. Okunaka, and T. Mizuyama (2008), Effects of bedrock groundwater on spatial and temporal variations in soil mantle groundwater in a steep granitic headwater catchment, Water Resour. Res., 44, W09430, doi:10.1029/2007WR006610.

Kosugi, K., S. Katsura, M. Katsuyama, and T. Mizuyama (2006), Water flow processes in weathered granitic bedrock and their effects on runoff generation in a small headwater catchment, Water Resour. Res., 42, W02414, doi:10.1029/2005WR004275.

Kosugi, K., S. Katsura, T. Mizuyama, S. Okunaka, and T. Mizutani (2008), Anomalous behavior of soil mantle groundwater demonstrates the major effects of bedrock groundwater on surface hydrological processes, Water Resour. Res., 44, W01407, doi:10.1029/2006WR005859.

Lambe, W. T., and R. Whitman (1979), Soil Mechanics, SI Version, John Wiley, New York.

Laudon, H., and O. Slaymaker (1997), Hydrograph separation using isotopes, silicia and electrical conductivity: An alpine example, J. Hydrol., 201(1-4), 82-101.

Liniger, M. (2006), Die Herausforderung der Gefahrenprognose bei Massenbewegungen: Rutsch und Sturzprozesse, Bull. Angew. Geol., 22(2), 75-88.

Loke, M. H. (2013), Tutorial: 2-D and 3-D electrical imaging surveys, Geotomo Software, Malaysia.

Maries, G. (2011), Strength and geophysical profiling of a study site at Rufiberg, Canton Schwyz, CH, MS thesis, Inst. for Geotech. Eng., ETHZ, Zurich, Switzerland.

Mathewson, C. C., J. Keaton, and P. Santi (1990), Role of bedrock ground water in the initiation of debris flows and sustained post-flow stream discharge, Bull. Assoc. Eng. Geol., 27(1), 73-83.

Matsushi, Y., and Y. Matsukura (2007), Rainfall thresholds for shallow landsliding derived from pressure-head monitoring: Cases with permeable and impermeable bedrocks in Boso Peninsula, Japan, Earth Surf. Processes Landforms, 32, 1308-1322, doi:10.1002/esp.1491.

McDonnell, J. J. (2003), Where does water go when it rains? Moving beyond the variable source area concept of rainfall-runoff response, Hydrol. Processes, 17, 1869-1875, doi:10.1002/hyp.5132.

Montgomery, D. R., W. Dietrich, and J. Heffner (2002), Piezometric response in shallow bedrock at CB1: Implications for runoff generation and landsliding, Water Resour. Res., 38(12), 1274, doi:10.1029/ 2002WR001429.

Montgomery, D. R., W. Dietrich, R. Torres, S. Anderson, J. Heffner, and K. Loague (1997), Hydrologic response of a steep, unchanneled valley to natural and applied rainfall, Water Resour. Res., 33(1), 91-109.

Montgomery, D. R., K. M. Schmidt, W. E. Dietrich, and J. McKean (2009), Instrumental record of debris flow initiation during natural rainfall: Implications for modeling slope stability, J. Geophys. Res., 114, F01031, doi:10.1029/2008JF001078.

Onda, Y., Y. Komatsu, M. Tsujimura, and J.-i. Fujihara (2001), The role of subsurface runoff through bedrock on storm flow generation, Hydrol. Processes, 15, 1693-1706, doi:10.1002/hyp.234.

Onda, Y., M. Tsujimura, and H. Tabuchi (2004), The role of subsurface water flow paths on hillslope hydrological processes, landslides and landform development in steep mountains of Japan, Hydrol. Processes, 18, 637-650, doi:10.1002/hyp.1362.

Oosterbaan, R. J., and H. J. Nijland (1994), Determining the saturated hydraulic conductivity, in Drainage Principles and Applications, edited by H. P. Ritzema, Chap. 12, Publication 16, revised edition, Int. Ins. for Land Reclam. and Impr., Wageningen, Netherlands.

Palacky, G.J. (1987), Resistivity characteristics of geological targets, in Electromagnetic Methods in Applied Geophysics Theory, SEG Invest. in Geophys. Series 3, vol. 1, edited by M. N. Nabighian, pp. 53-129, Soc. Explor. Geophys., Tulsa, Okla.

Rickli, C., H. Raetzo, B. McArdell, and J. Presler (2008), Hanginstabilitäten, in Ereignisanalyse Hochwasser 2005 Teil 2-Analyse von Prozessen, Massnahmen und Gefahrengrundlagen, edited by G. R. Bezzola, and C. Hegg, pp. 84, Bundesamt für Umwelt BAFU, Bern und der 


\section{BRÖNNIMANN ET AL.: BEDROCK EXFILTRATION: SHALLOW LANDSLIDE TRIGGERING MECHANISM}

Eidgenössischen Forschungsanstalt für Wald, Schnee und Landschaft WSL, Birmensdorf, Switzerland.

Schmid, F., M. Fraefel, and C. Hegg (2004), Unwetterschäden in der Schweiz 1972-2002: Verteilung, Ursachen, Entwicklung, Wasser, Energie und Luft, 1(2), 21-28.

Schneider, P., L. Strouhal, S. Pool, and J. Seibert (2013), True colors changing perceptions of hydrological processes at a hillslope prone to slide, Hydrol. Earth Syst. Sci. Discuss., 10, 8233-8277, doi:10.5194/ hessd-10-8233-2013.

Springman, S. M., A. Askarinejad, F. Casini, S. Friedel, P. Kienzler, P. Teysseire, and A. Thielen (2012), Lessons learnt from field tests in some potentially unstable slopes in Switzerland, Acta Sloven. Geotech., 1, 5-29.

Topp, G. C., J. L. Davis, and A. P. Annan (1980), Electromagnetic determination soil water content: Measurements in coaxial transmission lines, Water Resour. Res., 16(3), 574-582.

Tromp-van Meerveld, H. J., and M. Weiler (2008), Hillslope dynamics modeled with increasing complexity, J. Hydrol., 361(1-2), 24-40, doi:10.1016/j.jhydrol.2008.07.019.

Uchida, T., Y. Asano, N. Ohte, and T. Mizuyama (2003), Seepage area and rate of bedrock groundwater discharge at a granitic unchanneled hillslope, Water Resour. Res., 39(1), 1018, doi:10.1029/2002WR001298.
Uchida, T., K. Kosugi, and T. Mizuyama (2002), Effects of pipe flow and bedrock groundwater on runoff generation in a steep headwater catchment in Ashiu, central Japan, Water Resour. Res., 38(7), 1119, doi:10.1029/2001WR000261.

Van Asch, T. W. J., J. Buma, and L. P. H. Van Beek (1999), A view on some hydrological triggering systems in landslides, Geomorphology, 30, 25-32.

Wang, G. and K., Sassa (2003), Pore-pressure generation and movement of rainfall-induced landslides: Effects of grain size and fineparticle content, Eng. Geol., 69, 109-125, doi:10.1016/S00137952(02)00268-5.

Weiler, M., J. McDonnell, I. Tromp-van Meerveld, and T. Uchida (2006), Subsurface stormflow, in Encyclopedia of Hydrological Sciences, edited by M. G. Anderson and J. J. McDonnell, pp. 1719-1732, John Wiley, New York.

Wilson, C. J., and W. E. Dietrich (1987), The contribution of bedrock groundwater flow to storm runoff and high pore pressure development in hollows, paper presented at the Int. Symp. on Erosion and Sedimentation in the Pacific Rim, 3-7 August 1987, Corvallis, Oreg., publ. 165, pp. 4959, Int. Assoc. Hydrol. Sci. Bull., Wallingford, U. K. 